\title{
THE EVOLUTION OF CHEMICAL ALARM SIGNALS: ATTRACTING PREDATORS BENEFITS ALARM SIGNAL SENDERS
}

\author{
Douglas P. Chivers, ${ }^{*}$ Grant E. Brown, and R. Jan F. Smith \\ Department of Biology, University of Saskatchewan, 112 Science Place, \\ Saskatoon, Saskatchewan S7N 5E2, Canada
}

Submitted June 14, 1995; Revised November 30, 1995; Accepted December 15, 1995

\begin{abstract}
A wide variety of organisms possess damage-released alarm pheromones that evoke antipredator responses in conspecifics. Understanding the evolution of such involuntary alarm signals has been perplexing because it is difficult to see direct benefits to the sender, notwithstanding benefits derived from warning relatives. Recently, it has been proposed that the alarm pheromone, or Schreckstoff, of Ostariophysan fishes may function in a fashion analogous to distress calls of many birds and mammals. The alarm pheromone may attract secondary predators to the proximity of the primary predation event, and, once there, the secondary predators may disrupt the predation event, thus allowing the prey greater opportunity to escape. Previous findings have established that the alarm pheromone of fathead minnows (Pimephales promelas) attracts predators, including northern pike (Esox lucius) to an area. In this study we demonstrate that the probability that fathead minnows will escape after being captured by a northern pike is significantly increased through interference by a second pike. Taken with the previous findings that alarm pheromone attracts predators, these results are the first to provide empirical evidence of benefits to senders of an involuntary alarm signal.
\end{abstract}

The evolution of alarm signaling is one of the most elusive issues in behavioral ecology (Williams 1964, 1992; Taylor et al. 1990). Mathis et al. (1995) argue that the puzzle may be especially perplexing when dealing with damage-released chemical alarm signals, because it is difficult to see any direct benefits to the sender, aside from benefits derived from warning kin. Damage-released chemical alarm signals have been reported in a variety of taxa, including gastropods (Atema and Stenzler 1977; Stenzler and Atema 1977), echinoderms (Snyder and Snyder 1970), crayfish (Hazlett 1994), amphibians (Hews and Blaustein 1985; Hews 1988), and a variety of fishes, including darters, gobies, sculpins, stickleback, and members of the superorder Ostariophysi (minnows, characins, catfishes, loaches, suckers, and gonorhynchiforms), which make up at least $70 \%$ of all freshwater fish species (review in Smith 1992).

It has been noted (Smith 1992) that alarm pheromone (Schreckstoff) of Ostariophysan fishes is released at the same point in the predation sequence as that when many animals give distress calls (e.g., juvenile alligators: Staton 1978; fishes: Myrberg 1981; mammals: Sherman 1985; birds: Koenig et al. 1991; frogs: Kana-

\footnotetext{
* Present address: Department of Zoology, Oregon State University, 3029 Cordley Hall, Corvallis, Oregon 97331-2914; E-mail: Chiversd@bcc.orst.edu.
} 
madi et al. 1993). Distress calls may function to attract other conspecifics and heterospecifics that mob the predator and drive it off (Curio et al. 1978) or to attract additional predators that disrupt the predation event, which allows the prey an opportunity to escape (Perrone 1980; Högstedt 1983; Koenig et al. 1991). The alarm pheromone of ostariophysans may function in a fashion analogous to distress calls of many birds and mammals in that it may attract predators that disrupt the predation event and allow the prey an opportunity to escape (Smith 1992).

Recently, Mathis et al. (1995) provided empirical evidence that juvenile northern pike (Esox lucius) and dytiscid diving beetles (Colymbetes sculptilis), both predators of fathead minnows (Pimephales promelas), are attracted to minnow alarm pheromone. In their study the predators were more attracted to skin extracts of nonbreeding fathead minnows (which have alarm pheromone cells) than to skin extracts of breeding male fathead minnows (which lack alarm pheromone cells) (Smith 1973). In other predator-prey systems, predators are attracted to chemical stimuli of disturbed or injured prey. Tester (1963) demonstrated that agitated and distressed groupers (Epinephelus merra) released chemical stimuli that were more attractive to gray sharks (Carcharhinus menisorrah) and blacktip sharks (Carcharhinus melanopterus) than chemicals from undisturbed groupers. A similar effect occurred with blacktip sharks responding to chemicals from excited and distressed mullet (Mugil cephalus) (Tester 1963). As well, garter snakes (Thamnophis sirtalis) are attracted to chemical alarm pheromones released by earthworms (Lumbricus terrestris) (Halpern et al. 1986).

Because predators are attracted to alarm pheromone of fathead minnows, secondary predators may disrupt predation events and increase the probability for the prey to escape. Several researchers (e.g., Smith and Lemly 1986; Reist et al. 1987; Reimchen 1988; Matity et al. 1994) have shown that small prey fishes from natural populations exhibit scars from failed predator attempts. Therefore, it is possible that senders of alarm signals may survive to receive direct benefits by the release of their own alarm signal. Mathis et al. (1995) provide anecdotal evidence that interference by a secondary predator may allow prey to escape. Nevertheless, no empirical tests of this hypothesis have been conducted. In this study, we test whether the presence of a secondary predator (i.e., northern pike) increases the probability that fathead minnows will escape after being captured by a primary predator.

Pike are mainly piscivores, with greater than $90 \%$ of their diet consisting of other fish, including conspecifics (Lawler 1965). Juvenile pike typically inhabit inshore vegetated regions of lakes and rivers, often in turbid water (Savino and Stein 1989). In the often densely vegetated habitat occupied by juvenile pike, chemical cues would likely be of prime importance in their foraging behavior. Mathis et al. (1995) have shown that juvenile pike are attracted by chemical alarm cues released by injured minnows. Once attracted by chemical cues to within visual range of prey, pike visually fixate on prey and strike over a short distance (Webb 1982). Under natural conditions the role of chemical cues in initiating a secondary pike to interfere with a primary pike would likely be to attract the secondary pike to within a range where visual cues would take over. Visual cues 
alone may initiate attraction of a secondary pike to interfere; however, this would likely be quite rare because dense vegetation would most often preclude pike from being within visual proximity.

Fathead minnows frequently occupy the same vegetated habitat as juvenile pike. If a minnow escapes from a pike in this habitat, it would likely be able to move quickly to outside the visual range of the pike. When escaping from pike, minnows typically dash, seek cover, and freeze (i.e., remain motionless for an extended period of time). Even if a minnow does not flee far enough to be outside the pike's visual range, being cryptic for a sufficiently long time may allow a minnow to avoid detection.

If secondary predators, which are attracted by alarm pheromone, disrupt a predation event, allowing the prey to escape, our results would be the first to provide evidence of direct benefits to the senders of a chemical alarm signal. Other hypotheses for the evolution of alarm pheromones, including an antipathogen function, and warning of kin are not incompatible with the secondary predator hypothesis, and these are not addressed in our study (see Smith 1977, 1992, for reviews of other hypotheses).

\section{METHODS}

\section{Collection and Maintenance}

In the spring of 1994 we collected fathead minnows from Pike Lake, an oxbow lake of the South Saskatchewan River in central Saskatchewan, Canada, where they occur in sympatry with northern pike. The minnows were maintained in a $300-\mathrm{L}$ artificial stream tank at approximately $18^{\circ} \mathrm{C}$ on a $14 \mathrm{~L}: 10 \mathrm{D}$ cycle, and they were fed daily with Nutrafin Goldfish Food. All minnows were maintained in the laboratory for a minimum of $8 \mathrm{wk}$ before testing.

Young-of-the-year northern pike were collected from Van Pattens Creek in central Saskatchewan in June 1994 and were maintained at approximately $18^{\circ} \mathrm{C}$ on a 14L:10D cycle. The pike were fed one to two fathead minnows every $2 \mathrm{~d}$ for a minimum of $3 \mathrm{wk}$ before testing.

\section{Testing Protocol}

To test whether secondary predators increase the probability of escape of fathead minnows that have been captured by a primary predator, we compared the occurrence of escapes in the absence of a secondary predator (control treatment) and in the presence of a secondary predator (experimental treatment). Aquaria, measuring $50 \times 25 \times 30 \mathrm{~cm}$, were filled with dechlorinated tap water and divided widthwise into two equal halves with a removable opaque barrier. Individual pike (primary pike, $N=16$ ) were placed into one randomly selected side of the aquaria on day 1 of the experiment and were fed a single fathead minnow. In the other compartment of half of the tanks we added a second pike, which was also fed one fathead minnow.

On day 3 we removed minnows from their holding tank, measured their fork length, and released one minnow into each of the primary pike's compartment. 
Ten seconds after the pike captured the minnow (i.e., held the minnow in its mouth for $5 \mathrm{~s}$ and hence began to release alarm pheromone), we removed the opaque barrier separating the primary predator and its captured prey from either an empty compartment (control treatment) or a secondary predator (experimental treatment).

During each trial we recorded whether the minnow escaped from the predator, the time taken to consume the minnow (handling time), and whether the secondary predator interfered directly or indirectly with the primary predator. For a minnow to be considered as having "escaped," it had to free itself from the grasp of the primary predator for a minimum of $5 \mathrm{~s}$ and be at least two pike body lengths away from the primary pike. For our criterion of an escape, we chose two body lengths of the pike as the minimum distance that the minnow would have to be away from the pike because this is a distance outside the normal attack range of Esocid fishes (Webb and Skadsen 1984). Given that under natural conditions juvenile pike typically occupy vegetated habitats, a minnow that escapes from a pike for $5 \mathrm{~s}$ and makes it at least two pike body lengths away from the pike would likely have a good chance of reaching refuge or fleeing far enough away from the predator not to be recaptured. When consuming minnows, juvenile pike typically capture the minnow near the midpoint then turn it in their mouth until it can be swallowed headfirst (Webb 1984). The handling time was calculated as the time from initial capture of the minnow, and hence release of alarm pheromone, until the entire dorsal fin of the minnow was no longer visible. Laboratory observations indicate that minnows cannot escape from pike this late in a predation sequence (D. P. Chivers, G. E. Brown, and R. J. F. Smith, personal observation). In experimental trials (trials with a secondary pike), we considered the second pike to have directly interfered with the primary pike if it contacted the primary pike with its mouth or indirectly interfered if it swam to within one body length of the primary pike and oriented toward the struggling prey. During direct interference, the secondary pike often bite the primary pike around the opercula, which results in the primary pike opening its jaws, allowing the prey to escape. Alternatively, the secondary pike would bite the minnow and attempt to pull the minnow away from the primary pike.

After completing trials on day 3 , we removed the secondary pike from the tanks containing two pike and added a second pike to tanks containing a single pike. Secondary pike were used in only one test. Two days later (day 5) we repeated the experiment using the same protocol. Primary pike tested in the control treatment on day 3 were tested in the experimental treatment on day 5 , and primary pike tested in the experimental treatment on day 3 were tested in the control treatment on day 5. This controlled for any effects related to the sequence of testing.

Mean $( \pm$ SD) fork length of primary pike in our study was $9.2 \pm 1.0 \mathrm{~cm}$. The size of minnows used on day 3 and day 5 were matched for size for each pike. The minnows (mean $[ \pm \mathrm{SD}]$ fork length $=4.6 \pm 0.3$ ) averaged $50 \%$ of the length of the primary pike. This prey size range is well within the typical prey size range for juvenile pike. Juvenile pike frequently consume minnows greater than $70 \%$ of their total body length (D. P. Chivers, G. E. Brown, and R. J. F. Smith, 
personal observation). The mean ( \pm SD) fork length of secondary pike was 10.7 $\pm 1.1 \mathrm{~cm}$. In all cases the secondary pike were slightly larger than the primary pike (mean size difference $=14 \%$ ). Preliminary observations indicated that, generally, secondary pike interfered most often when they were slightly larger than the primary pike. However, we have observed instances when secondary pike interfered with primary pike larger than themselves.

Under natural conditions pike typically occupy vegetated habitats, often in turbid water along the shoreline of lakes and rivers (Savino and Stein 1989). Under such conditions chemical cues are likely very important in initiating foraging behavior in pike. Mathis et al. (1995) have established that pike are attracted to minnow alarm pheromone released in an area visually isolated from the pike. Once attracted to within visual range of a primary predation event, vision could take over to initiate interference by the secondary pike. In our experiment, the sight (and not alarm substance) of the primary pike struggling with the minnow likely attracted the secondary pike to interfere. We could not conduct the experiment under conditions that eliminated visual cues to the secondary predator without also interfering with the observers' ability to witness interference and escapes. In our experiment, attraction of pike by visual cues does not confound our results because we were only interested in testing whether the presence of a secondary pike resulted in an increased probability that the minnows would escape. Mathis et al. (1995) have already established that minnow alarm pheromone attracts pike to the area.

We used a Fisher's exact probability test (Siegel and Castellan 1988) to compare the total number of trials in which minnows escaped in control versus experimental treatments. We calculated the difference in the handling times for each pike in the control versus experimental treatments and compared these differences using a Wilcoxon signed-rank test (Siegel and Castellan 1988). Because we compared the differences in handling time (i.e., handling time in the experimental treatment minus handling time in the control treatment), only trials in which the primary pike consumed the minnow in both trials were used. By using each fish as its own control, we reduced effects of interpike variability in handling time. Because we predicted that interference by secondary predators should increase the handling time of the primary pike, we used one-tailed statistical tests in which $\alpha=0.05$.

\section{RESULTS}

In three of the 16 trials, the primary pike did not attempt to capture the prey within $15 \mathrm{~min}$ on day 3 ; therefore, these trials were abandoned. We observed direct interference by the secondary predator in 10 of the 13 experimental trials and indirect interference in the remaining three trials. As a result of direct interference, minnows escaped in five of the trials. In one of these trials, the minnow escaped twice, once as a result of indirect interference and once as a result of direct interference. In three of five of the trials in which the minnow escaped through direct interference, the minnow was eventually consumed by the secondary pike, and in two cases the minnow was eventually consumed by the primary 
TABLE 1

\begin{tabular}{lcc}
$\begin{array}{c}\text { Number of Trials in Which Minnows Escaped } \\
\text { From the Primary Pike }\end{array}$ \\
\hline \hline Treatment & $\begin{array}{l}\text { Trials with } \\
\text { an Escape }\end{array}$ & $\begin{array}{c}\text { Trials without } \\
\text { an Escape }\end{array}$ \\
\hline Control & 0 & 13 \\
Experimental & 5 & 8 \\
\hline Note.-Control trials were conducted in the ab- \\
sence of a secondary predator, and experimental trials \\
were conducted in the presence of a secondary preda- \\
tor. Significance level, $P$, is .0196.
\end{tabular}

pike. Duration of time after escaping, before recapture, ranged from 6 to $22 \mathrm{~s}$ (mean $[ \pm \mathrm{SD}]=12.5 \pm 7.1 \mathrm{~s}$ ). Although all of the minnows that escaped were eventually recaptured in a subsequent attack by the predator, it is likely that under natural conditions some of these minnows would have been able to reach refuge or flee far enough away from the pike not to be recaptured. In 13 control trials there were no instances in which the minnow escaped from the pike. Significantly more escapes occurred in experimental trials than in control trials (table 1).

Nine of the primary pike consumed the minnows in both the control and experimental trials. Handling times were significantly longer during experimental trials than control trials (Wilcoxon signed-rank test, $T+=37, N=9, P<.05$ ) (fig. $1)$.

\section{DISCUSSION}

Our results clearly demonstrate that the probability that fathead minnows will escape from a predator is increased by interference by a second predator. Taken in conjunction with the previous finding of Mathis et al. (1995) that alarm pheromone attracts secondary predators, these results are the first to provide evidence of direct benefits to senders of an involuntary alarm signal.

Other studies have suggested or demonstrated direct benefits to senders of voluntary alarm signals given before the prey is captured. For example, alarm signals that appear directed toward predators (e.g., Shalter 1978; Woodland et al. 1980; Hasson 1991) may benefit the sender by reducing the probability that the predator will initiate an attack (Sherman 1985). Sherman (1985) demonstrated that Belding's ground squirrels (Spermophilus beldingi), which give alarm calls upon detecting aerial predators, have a significantly lower probability of being captured than individuals that do not give alarm calls.

In our study, the presence of a second pike significantly increased the handling time of the primary pike. The increase in handling time resulted from the primary pike struggling with the secondary pike or, alternatively, from the primary pike being more cautious when manipulating the prey. Even though the primary pike seemed more cautious in manipulating the minnow, the increase in handling time would likely increase the time available for the minnows to escape. Under natural 


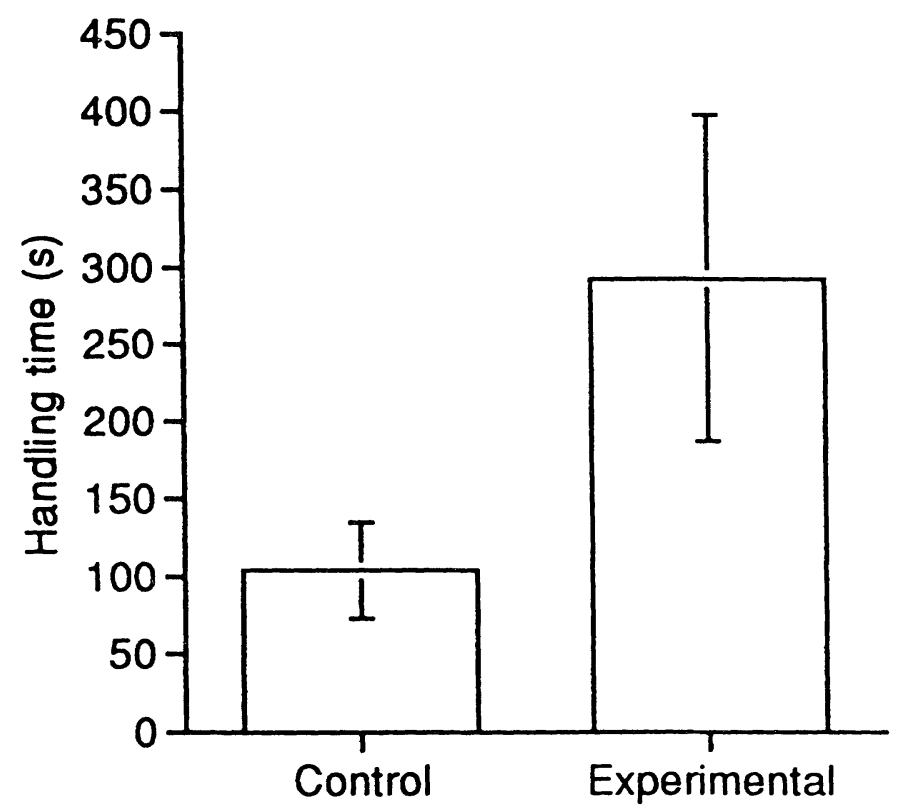

FIG. 1.-Mean ( \pm SE) handling time of primary pike in the absence of a secondary pike (control treatment) and in the presence of a secondary pike (experimental treatment). Means and SEs are used to illustrate trends in the data only. Statistical comparison was made with a Wilcoxon signed-rank test (see text).

conditions the probability of escape may be further enhanced if longer handling time allows the arrival of additional predators.

We do not know how fast alarm pheromone attracts secondary predators to an area under natural conditions; however, this speed should depend on the speed at which alarm pheromone emanates from the prey and the distance between the primary and secondary predators. The speed that alarm pheromone travels will be influenced by current speed and turbulence, which will be enhanced by struggling of the prey.

A minnow's club cells contain a limited amount of alarm pheromone that is released upon mechanical damage to the cells. As a result, once a cell is ruptured and the pheromone is released, the minnow will not continue to secrete alarm pheromone. Pike can follow the odor trail of an alarm pheromone, as demonstrated by Mathis et al. (1995), but only when the pheromone is being released. A minnow that escapes an attack and flees from the pheromone plume would not continually release an alarm pheromone trail that could be followed by pike.

The active space of alarm pheromone contained within $1 \mathrm{~cm}^{2}$ of minnow skin has been estimated at 58,000 L or a 3.9-m cube (Lawrence and Smith 1989). The time of activity of alarm pheromone is likely relatively short as, even in habitats with little current, the pheromone would be rapidly diluted to the point where it would no longer elicit a response (Lawrence and Smith 1989).

In Pike Lake, two of us (D.P.C. and G.E.B.) have observed 14 juvenile pike 
spread out along a 10-m section of shoreline. Ultraviolet fluorescent dye released in this area on a calm day spread to a diameter of $1 \mathrm{~m}$ in a mean ( \pm SD) of 36.4 $\pm 7.8 \mathrm{~s}(n=10)$. Given that the handling time of the minnows in our study averaged $104 \mathrm{~s}$ (in the absence of a secondary predator), this amount of time would likely be sufficient for secondary predators to be attracted to the area and disrupt the predation event even at densities considerably less than these. Furthermore, in laboratory tests Mathis et al. (1995) showed that pike may move to an area containing alarm pheromone within less than $1 \mathrm{~min}$. Secondary predators need only be attracted into visual range of the predation event.

The mean handling time of $104 \mathrm{~s}$ in our study (in the absence of a second pike) was related to the relative size of the prey to the predator. The average size of the minnows was $50 \%$ of the body length of the pike. Given that minnows greater than $70 \%$ of the body size of a pike are frequently captured by juvenile pike (D. P. Chivers, G. E. Brown, and R. J. F. Smith, personal observation), handling time may often be even higher than that recorded in our study. This should act to further increase the probability that sufficient time would be available for a secondary pike to interfere. When minnows are captured by predators that are substantially larger than themselves, the handling time of the predators should be very short, and the opportunity for interference therefore should be minimal. However, given that pike have a Type I mortality curve (i.e., a juvenile-biased population structure; Treasurer et al. 1992) and indeterminate growth, minnows should most frequently encounter young (i.e., small) pike, as opposed to older pike.

The relative size difference between the primary and secondary predators is another factor that should likely influence the probability of escape of a minnow. Many predators, including pike, are cannibalistic (Lawler 1965). In our study, secondary predators were not a predation threat to the primary predators. However, if alarm pheromone attracts secondary predators that do pose a threat to the primary predators, the primary predator might release the minnow to flee itself. Abrahams and Townsend (1993) argue that bioluminescence in dinoflagellates may have evolved through a similar type of selection. In their study, bioluminescence by dinoflagellates (Gonyalaux polyedra) attracted stickleback (Gasterosteus aculeatus), which cause significant mortality on copepods (Tigriopus japonicus), the predators of dinoflagellates.

Our results are the first to provide empirical evidence of benefits to senders of an involuntary alarm signal. Secondary predators that are attracted to the alarm pheromone of fathead minnows disrupt the predation event, which allows the prey an opportunity to escape. If alarm pheromones evolved through direct benefits to the sender via secondary predator interference, the selection pressure leading to alarm responses in prey receivers may be explained independent of selection on senders. Prey that detect alarm pheromone would benefit by performing antipredator behavior for two reasons. First, the release of alarm pheromone is a reliable indicator that the sender has been injured and hence that a predator has attacked or captured a conspecific in the vicinity (Chivers and Smith $1994 a, 1994 b)$. Second, if the pheromone attracts more predators, then defensive behavior by prey will be doubly beneficial. This second mechanism makes the 
evolution of prey responses to alarm pheromone more easily understood. The secondary predator hypothesis for the evolution of damage-released alarm pheromones is not inconsistent with other hypotheses for alarm pheromone evolution, including an antipathogen function, and warning of kin.

Male fathead minnows, but not females, lose their alarm pheromone cells during the spawning season. During this time male minnows aggressively defend spawning sites and rub against spawning surfaces, potentially damaging alarm pheromone cells and releasing alarm pheromone (Smith 1977). It has been argued that this loss of alarm pheromone cells reduces the probability of frightening potential mates because of the inadvertent release of alarm pheromone (Smith 1977). These results and those of Mathis et al. (1995) suggest that this seasonal loss of alarm pheromone cells would also reduce the probability of attracting predators. The absence of alarm pheromone cell loss by breeding female minnows may be a consequence of the fact that females do not engage in care of the brood. The absence of brood care by females means that they are not in a position to inadvertently release alarm pheromones that would attract predators.

We have established the essential elements of a system in which prey fish could benefit by releasing alarm pheromone at the time of injury. Predators are attracted by alarm pheromone (Mathis et al. 1995). Predator densities and alarm pheromone diffusion rates are sometimes sufficient to bring secondary predators within visual range of the primary predation event during the handling time of the primary predator. Finally, the arrival and subsequent behavior of a secondary predator increases the probability that the captured prey will escape. In nature, secondary predators may sometimes approach using vision alone, but the release of attractive chemicals will increase the chance of drawing them into visual range when vision is obscured by weeds, sediment, or low light intensities. Such limits on vision are common in the habitats occupied by fathead minnows and juvenile pike.

Given that alarm or distress signals that follow capture by a predator are exhibited in many taxa (e.g., juvenile alligators: Staton 1978; fishes: Myrberg 1981, Smith 1992; mammals: Sherman 1985; birds: Koenig et al. 1991; frogs: Kanamadi et al. 1993) and that at least some of these signals attract predators (Tester 1963; Högstedt 1983; Halpern et al. 1986; Mathis et al. 1995), we suspect that interference by secondary predators could drive alarm signal evolution in many other predator-prey systems.

\section{ACKNOWLEDGMENTS}

We thank B. Wisenden, O. Hasson, R. Taylor, and R. Howard for providing helpful suggestions on earlier versions of the manuscript. Financial support was provided by the Natural Sciences and Engineering Research Council of Canada and the University of Saskatchewan.

LITERATURE CITED

Abrahams, M. V., and L. D. Townsend. 1993. Bioluminescence in dinoflagellates: a test of the burglar alarm hypothesis. Ecology 74:258-260. 
Atema, J., and D. Stenzler. 1977. Alarm substance of the marine mud snail, Nassarius obsoletus: biological characterization and possible evolution. Journal of Chemical Ecology 3:173-187.

Chivers, D. P., and R. J. F. Smith. 1994a. The role of experience and chemical alarm signalling in predator recognition by fathead minnows, Pimephales promelas. Journal of Fish Biology 44: 273-285.

1994b. Fathead minnows, Pimephales promelas, acquire predator recognition when alarm substance is associated with the sight of unfamiliar fish. Animal Behaviour 48:597-605.

Curio, E., U. Ernst, and W. Vieth. 1978. The adaptive significance of avian mobbing. II. Cultural transmission of enemy recognition in blackbirds: effectiveness and some constraints. Zeitschrift für Tierpsychologie 48:184-202.

Halpern, J., N. Schulman, and M. Halpern. 1986. Earthworm alarm pheromone is a garter snake chemoattractant. Chemical Senses 11:607-608.

Hasson, O. 1991. Pursuit-deterrent signals: communication between prey and predator. Trends in Ecology \& Evolution 6:325-329.

Hazlett, B. A. 1994. Alarm response in the crayfish Orconectes virilis and Orconectes propinquus. Journal of Chemical Ecology 20:1525-1535.

Hews, D. K. 1988. Alarm response in larval western toads, Bufo boreas: release of larval chemical by a natural predator and its effect on predator capture efficiency. Animal Behaviour 36: $125-133$.

Hews, D. K., and A. R. Blaustein. 1985. An investigation of the alarm response in Bufo boreas and Rana cascadae tadpoles. Behavioral and Neural Biology 43:47-57.

Högstedt, G. 1983. Adaptation unto death: function of fear screams. American Naturalist 121:562-570.

Kanamadi, R. D., H. Schneider, C. R. Hiremath, and C. S. Jirankali. 1993. Vocalization of the tree frog Polypedates maculatus (Rhacophoridae). Journal of Bioscience 18:239-245.

Koenig, W. D., M. T. Stanback, and P. N. Hooge. 1991. Distress calls in the acorn woodpecker. Condor 93:637-643.

Lawler, G. E. 1965. The food of the pike, Esox lucius, in Hemming Lake, Manitoba. Journal of the Fisheries Research Board of Canada 22:1357-1377.

Lawrence, B. J., and R. J. F. Smith. 1989. Behavioral response of solitary fathead minnows, Pimephales promelas, to alarm substance. Journal of Chemical Ecology 15: 209-219.

Mathis, A., D. P. Chivers, and R. J. F. Smith. 1995. Chemical alarm signals: predator deterrents or predator attractants? American Naturalist 145:994-1005.

Matity, J. G., D. P. Chivers, and R. J. F. Smith. 1994. Population and sex differences in antipredator responses of breeding fathead minnows (Pimephales promelas) to chemical stimuli from garter snakes (Thamnophis radix and T. sirtalis). Journal of Chemical Ecology 20:2111-2121.

Myrberg, A. A. 1981. Sound communication and interception in fishes. Pages 395-452 in W. Tavolga, A. N. Popper, and R. R. Fay, eds. Hearing and sound communication in fishes. Springer, New York.

Perrone, M., Jr. 1980. Factors affecting the incidence of distress calls of passerines. Wilson Bulletin 92:404-408.

Reimchen, T. E. 1988. Inefficient predators and prey injuries in a population of giant stickleback. Canadian Journal of Zoology 66:2036-2044.

Reist, J. D., R. A. Bodaly, R. J. P. Fudge, K. J. Cash, and T. V. Stevens. 1987. External scarring of whitefish, Coregonus nasus, and C. clupeaformis complex, from the western Northwest Territories, Canada. Canadian Journal of Zoology 65:1230-1234.

Savino, J. F., and R. A. Stein. 1989. Behavior of fish predators and their prey: habitat choice between open water and dense vegetation. Environmental Biology of Fishes 24:287-293.

Shalter, M. D. 1978. Localization of passerine seet and mobbing calls by goshawks and pygmy owls. Zeitschrift für Tierpsychologie 46:260-267.

Sherman, P. W. 1985. Alarm calls of Belding's ground squirrels to aerial predators: nepotism or self-preservation? Behavioral Ecology and Sociobiology 17:313-323.

Siegel, S., and N. J. Castellan. 1988. Nonparametric statistics for the behavioral sciences. $2 d$ ed. McGraw-Hill, New York.

Smith, R. J. F. 1973. Testosterone eliminates alarm substance in male fathead minnows. Canadian Journal of Zoology 41:875-876. 
1977. Chemical communication as adaptation: alarm substance of fish. Pages 303-320 in D. Müller-Schwarze and M. M. Mozell, eds. Chemical signals in vertebrates. Plenum, New York.

1992. Alarm signals in fishes. Reviews in Fish Biology and Fisheries 2:33-63.

Smith, R. J. F., and A. D. Lemly. 1986. Survival of fathead minnows after injury by predators and its possible role in the evolution of alarm signals. Environmental Biology of Fishes 15: 147-149.

Snyder, N. F. R., and H. A. Snyder. 1970. Alarm response of Diadema antillarum. Science (Washington, D.C.) 168:276-278.

Staton, M. A. 1978. "Distress calls" of crocodillians-whom do they benefit? American Naturalist 112:327-332.

Stenzler, D., and J. Atema. 1977. Alarm response of the marine mud snail, Nassarius obsoletus: specificity and behavioral priority. Journal of Chemical Ecology 3:159-171.

Taylor, R. J., D. F. Balph, and E. Balph. 1990. The evolution of alarm calling: a cost-benefit analysis. Animal Behaviour 39:860-868.

Tester, A. L. 1963. The role of olfaction in shark predation. Pacific Science 17:145-170.

Treasurer, J. W., R. Owen, and E. Bowers. 1992. The population dynamics of pike, Esox lucius, and perch, Perca fluviatilis, in a simple predator-prey system. Environmental Biology of Fishes 34:65-78.

Webb, P. W. 1982. Avoidance responses of fathead minnows to strikes by four teleost predators. Journal of Comparative Physiology A, Sensory, Neural, and Behavioral Physiology 147: 371-378.

1984. Body and fin form and strike tactics of four teleost predators attacking fathead minnow (Pimephales promelas) prey. Canadian Journal of Fisheries and Aquatic Sciences 41: 157-165.

Webb, P. W., and J. M. Skadsen. 1980. Strike tactics of Esox. Canadian Journal of Zoology 58: 1462-1469.

Williams, G. C. 1964. Measurement of consociation among fishes and comments on the evolution of schooling. Publications of the Museum, Michigan State University Biological Series 2: 349-384.

1992. Natural selection: domains, levels, and challenges. Oxford University Press, Oxford.

Woodland, D. J., Z. Jaafar, and M.-L. Knight 1980. The "pursuit deterrent" function of alarm signals. American Naturalist 115:748-753. 